UNIVERSIDADE DE SÃO PAULO

FACULDADE DE FILOSOFIA, CIÊNCIAS E LETRAS DE RIBEIRÃO PRETO PROGRAMA DE PÓS-GRADUAÇÃO EM ENTOMOLOGIA

\title{
Small sparking flies: systematics of Pholeomyia Bilimek, 1867 (Diptera: Milichiidae: Milichiinae)
}

Pequenas moscas brilhantes: sistemática de Pholeomyia Bilimek, 1867 (Diptera:

Milichiidae: Milichiinae)

\section{Heloísa Fernandes Flores}

Dissertação apresentada à Faculdade de Filosofia, Ciências e Letras de Ribeirão Preto da Universidade de São Paulo, como parte das exigências para obtenção do título de Mestre em Ciências, obtido no Programa de Pós-Graduação em Entomologia 


\section{Resumo}

Milichiidae (Diptera: Schizophora) é uma família de moscas acaliptradas conhecidas pelo fascinante hábito cleptoparasita da maioria das espécies. Dentro da família, Milichiinae é a subfamília com o maior número de espécies descritas. Os machos de muitas espécies da subfamília apresentam pilosidade prateada dorsalmente no abdômen que os faz "relampejar", refletindo pequenos raios de luz quando enxameiam no início da manhã. Vários aspectos da sistemática do grupo precisam ser devidamente compreendidos, incluindo questões envolvendo as relações fillogenéticas entre os gêneros. Dentro da subfamília, Pholeomyia Bilimek, 1867 possui 39 espécies descritas, das quais 27 ocorrem na região Neotropical. O gênero não foi completamente revisto na literatura até o momento, e não há estudos que estabeleçam as relações filogenéticas entre as espécies ou mesmo hipóteses de monofilia do gênero baseadas em sinapomorfias não homoplásticas. Além disso, questões relacionadas a sinonímia de Pseudomilichia com Pholeomyia ainda permanecem. Aqui, a evolução de Milichiinae é discutida e uma hipótese filogenética de Pholeomyia baseada na morfologia de machos é apresentada. A análise filogenética incluiu 72 táxons terminais (57 espécies no grupo interno e 15 do grupo externo) e usou 67 caracteres morfológicos, resultando em uma única árvore mais parcimoniosa sob pesagem implícita. A monofilia de Pholeomyia é recuperada e o novo cladograma para a subfamília destaca as relações entre os gêneros de Milichiinae. Nossos resultados também corroboram que Pseudomilichia é sinônimo de Pholeomyia. O cladograma obtido com 57 espécies do gênero mostra quatro clados principais, cuja posição e composição de espécies podem encontrar algum nível de ajuste com a adição de informações do abdômen masculino na matriz de dados para 12 das espécies incluídas como terminais na análise. 


\section{INTRODUCTION}

\subsection{The family Milichiidae}

Milichiidae (Diptera: Schizophora), popularly known as 'jackal flies' due to the kleptoparasitism habit of most of the species, includes approximately 417 extant and ten fossil species described in 20 genera in the world (Brake, 2000; Swann, 2016). Compared to other fly families, the jackal flies are not particularly species-rich. Nevertheless, considering the undescribed specimens in collections around the world, the number of species to be described may move the diversity of the group to over 1,000 .

Milichiids are small flies, ranging in length from 1 to $6 \mathrm{~mm}$. The coloration of most species varies from light brown to black. Males of some genera, as Pholeomyia Bilimek, Milichiella Giglio-Tos and some others, may have silvery abdominal tergites. The family has a rather broad spectrum of morphological variation, and some species may resemble in some extent other families, as carnids, agromyzids, chloropids and even tachinids (Brake, 2000). This can make it difficult for non-trained entomologists to identify milichiids in collections around the world. Some morphological characters may help in separating the jackal flies from these families, such as the presence of a geniculate proboscis, the presence of both humeral and subcostal breaks, the closed cup cell, and the absence of the postgonites (Brake, 2000; Swann, 2010).

Descriptions of the natural history of the jackal flies demonstrate that they are also ecologically diverse (Brake, 2000) (Figure 1). There are reports of saprophagous, necrophagous and coprophagous larvae (Sabrosky, 1977; Ferrar, 1987; Papp \& Wheeler, 1998; Brake, 2000). Coprophagy is a habit present in adults of some species too (Sabrosky, 1959). At least seven genera have been documented to feed on nectar of Aristolochia flowers (Brantjes, 1980; Wolda \& Sabrosky, 1986).

Within the spectrum of sources of food for adults, one of them stands out: the kleptoparasitism. Kleptoparasitic interactions occur at least in eight genera. Adults feed on the preys of a variety of species of spiders or insects (Reduviidae, Asilidae, Mantidae, among others) (Robinson \& Robinson, 1977; Sivinski \& Stowe, 1980; Eisner, Eisner \& Deyrup, 1991; Sivinski, Marshall \& Petersson, 1999; Brake, 2000; Swann, 2008). In almost all cases, only females are kleptoparasites (Sivinski \& Stowe, 1980; Eisner, Eisner \& Deyrup, 1991) and it is hypothesized that kleptoparasitism provides an extra source of protein for egg maturation (Robinson \& Robinson, 1977; Brake, 2000). Kleptoparasitism may be related to the morphological diversity and to the geographical distribution of the family (Brake, 2000), 
providing an interesting model for understanding the transition of different life histories across time and space.

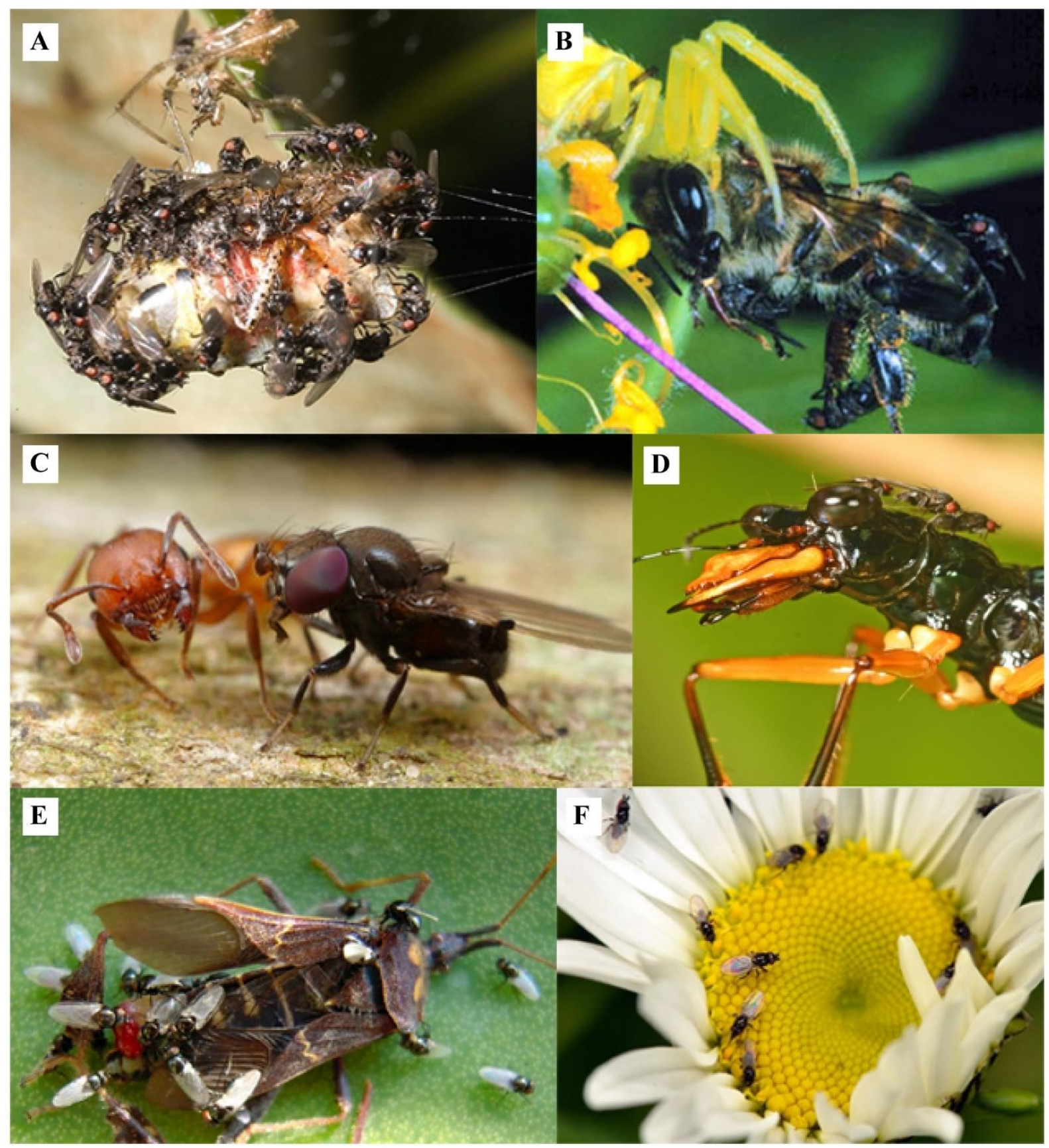

Figure 1. Illustrations of some jackal fly biologies. (A) Paramyia sp. feeding on the captured stink bug prey of a spider, photo by Steve A. Marshall. (B) Desmometopa sp. feeding on the bee prey of a crab spider, photo by Robert Copeland. (C) Milichia patrizii Hennig trying to trigger regurgitation of a Crematogaster ant, photo by Alex Wild. (D) Therates labiatus (Fabricius) with phoretic Paramyia sp., photo by Steve A. Marshall. (E) Milichiella lacteipennis (Loew) attracted to freshly killed female Leptoglossus zonatus (Dallas), photo by Takumasa Kondo. (F) Flowering plant visited by Paramyia sp., photo by Steve A. Marshall

It is considerably well established in the literature that Milichiidae is the sister group 
of Chloropidae within the Carnoidea. This is supported by some synapomorphies, as the lacinia of maxillae strongly reduced, the proboscis slightly elongated and geniculate, a bare anepisternum, the distiphallus short and glabrous, and the pocket-like ventral receptacle of the female terminalia. There is no dispute that the jackal flies are monophyletic. The most conspicuous synapomorphies of the clade are: upper orbital seta lateroclinate, middle orbital seta lateroclinate, lower orbital seta lateroclinate, two medioclinate frontal setae, presence of a proclinate setula between supra-antennal seta and eye margin, presence of a pair of setulae on the lunula, presence of four pseudotrachea, and absence of postgonites (Brake, 2000).

In older classifications, the milichiids were divided into the subfamilies Madizinae and Milichiinae. Hennig (1958) pointed out that Madizinae could be paraphyletic. Brake (2000), in fact, recovered in her phylogenetic analysis of the family a paraphyletic Madizinae. She subdivided the Madizinae sensu lato into the subfamilies Madizinae and Phyllomyzinae, and recovered Madizinae sensu stricto as the sister group of Milichiinae (Figure 2).

Swann (2010) disagreed with the subdivision of Madizinae s.l. into two subfamilies. He argued that Brake's (2000) analysis missed information on some characters for several terminals, which ended up as synapomorphies for several Phyllomyzinae taxa. Brake's (2000)

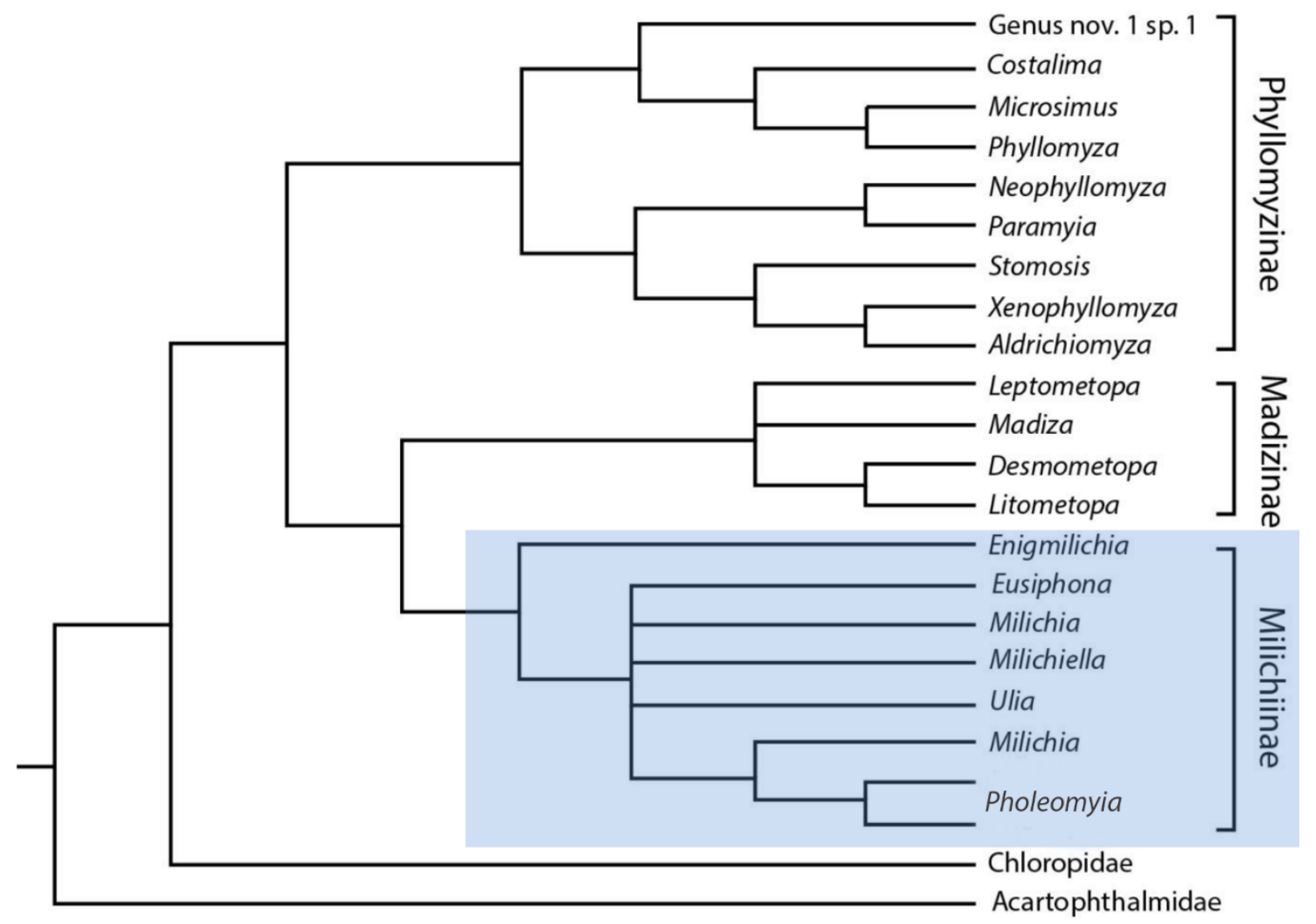

Figure 2. Brake's (2000) phylogenetic hypothesis for Milichiidae based on morphological characters. 
study is the only formal phylogenetic analysis of the relationships between the milichiid genera. Swann's (2010) comments are helpful as an analysis of the Brake's (2000) study, but are not a formal reanalysis of the group.

Brake (2000) brought a significant advance in the understanding of the evolution of morphological characters in the family, clarifying the phylogenetic relationship between some milichiid genera, but many questions still remain to be solved. Several genera need careful revisions and there are different pending issues on homology in the family, especially of mouthparts and male terminalia sclerites.

\subsection{The subfamily Milichiinae}

Milichiinae - the milichiid subfamily with largest number of described species comprises 226 extant species described in five genera in the world (Table 1). It includes the genera Enigmilichia Deeming, Eusiphona Coquillett, Milichia Meigen, Milichiella Giglio-Tos and Pholeomyia Bilimek (Brake, 2000) (Figure 3). The subfamily also has the largest number of described fossil species: seven Milichiella species from Dominican amber (Brake, 2006). In the other subfamilies, only two Phyllomyzinae fossils from Baltic amber and Mexican amber (Hennig, 1967; Sabrosky, 1963) and one Madizinae species from Baltic amber are known (Hennig, 1971).

Table 1. Diversity and geographic distribution of extant milichiines. Abbreviations: AF, Afrotopical; AU, Australia; NE, Nearctic; NT, Neotropical; PA, Palearctic; OR, Oriental.

\begin{tabular}{cccccccc}
\hline Táxon & $\mathbf{N}^{\mathbf{0}}$ of species & AF & AU & NE & NT & PA & OR \\
\hline Milichiinae & $\mathbf{2 0 3}$ & & & & & & \\
\hline Enigmilichia Deeming, 1981 & 1 & 1 & & & & & \\
\hline Eusiphona Coquillett, 1897 & 4 & & & 3 & 1 & & \\
\hline Milichia Meigen, 1830 & 39 & 21 & 4 & & & 10 & 6 \\
\hline Milichiella Giglio-Tos, 1895 & 120 & 20 & 14 & 23 & 47 & 6 & 11 \\
\hline Pholeomyia Bilimek, 1867 & 39 & & & 27 & 12 & & \\
\hline
\end{tabular}

The subfamily is considered monophyletic, a hypothesis supported by the following synapomorphies: enlarged eyes, obsolescent vibrissal angle, vibrissa above lower margin of eye, frons in males narrower than in females, and distal margin of anal cell meeting the anal vein at an acute angle (Brake, 2000). The group has been recovered as monophyletic, but the question of the relationships between the genera and the monophyly of the genera still demand investigation (Figure 2). Milichia and Pholeomyia are likely to be paraphyletic and the status 
of some genera previously described within the subfamily and later synonymized (as Pseudomilichia Becker) still remains controversial. It is necessary to increase the taxonomic sampling of all five milichiine genera to properly check their monophyly and address the internal relationships within the subfamily.

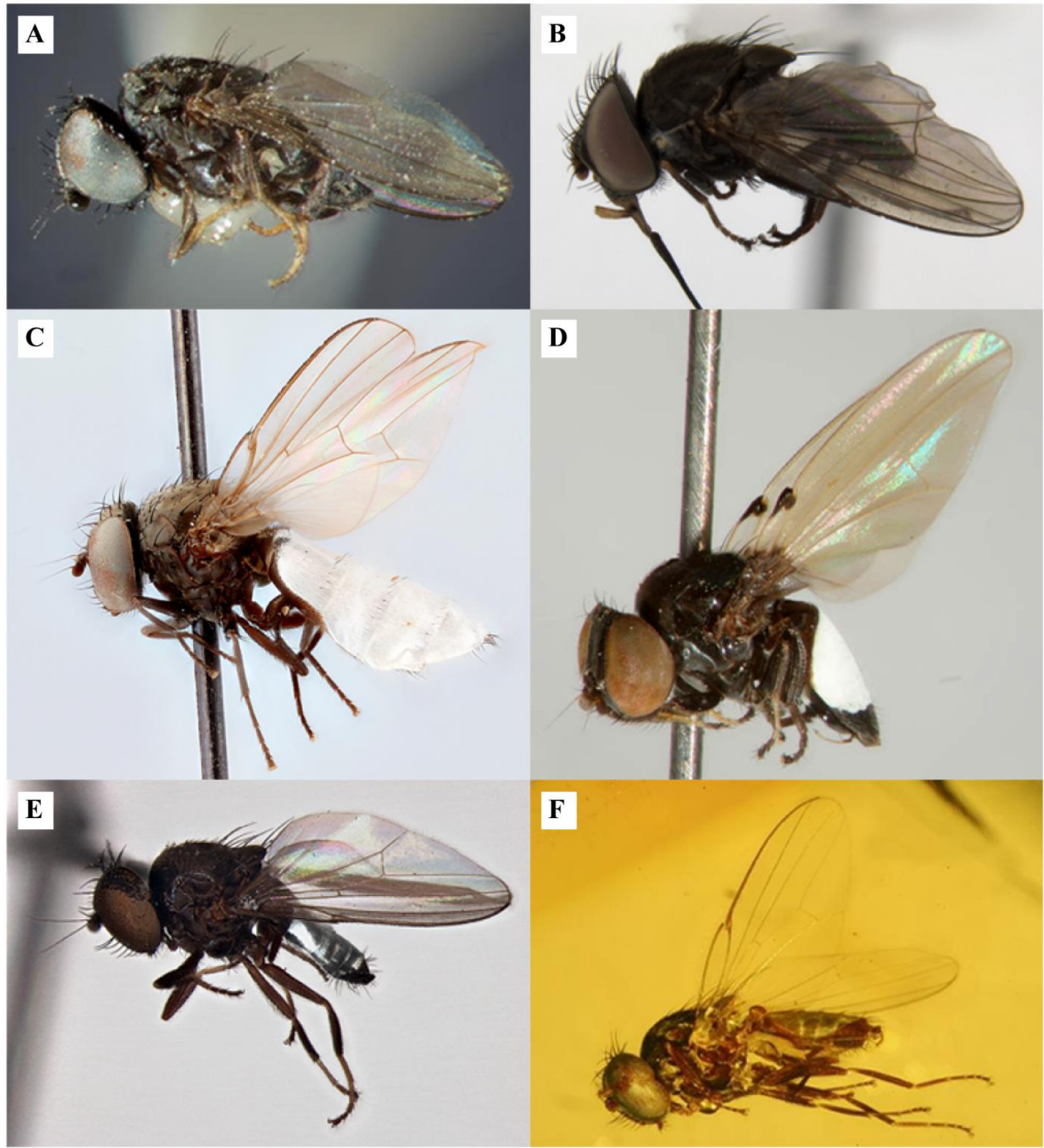

Figure 2. Representative species of the Milichiinae genera. (A) Enigmilichia dimorphica Deeming, Nigeria, photo by Irina Brake. (B) Eusiphona vittata Sabrosky, Brazil, photo by Heloísa Flores. (C) Pholeomyia vockerothi Sabrosky, United States, photo by Daniel Whitmore. (D) Milichia formicophila Deeming, Nigeria, photo by Irina Brake. (E) Milichiella sp., Brazil, photo by Heloísa Flores. (F) Milichiella margaretae Brake, Dominican Republic amber, photo by Irina Brake. 


\subsection{The genus Pholeomyia Bilimek, 1867}

According to the world catalog of the family (Brake, 2000), there are 39 species described in Pholeomyia (Table 2). The genus is mostly Neotropical, with 11 species known from the Nearctic region. Most Pholeomyia species were described by Becker (1907), Hendel (1932), and Sabrosky (1959). The only taxonomic review for the genus in the literature was provided by Sabrosky (1959), which includes all Nearctic and seven of the Neotropical species. Sabrosky (1959) study is the most recent paper to providing descriptions of new species in the genus-no Pholeomyia species have been described along the last 60 years.

Adults and larvae of Pholeomyia have an interesting biology. Males of most (but not all) of the species of the genus have silvery abdominal tergites, which reflect light while swarming, what allows them to be spotted over long distances (Sabrosky, 1973; Monteith, 1982; Swann, 2010). Pholeomyia larvae have been found in nests of Atta texana, where they feed on fungal garden debris (Sabrosky, 1959). Larvae of Pholeomyia have also been reported in nests of the Megachilidae bee (Sabrosky, 1955).

Brake (2000) recovered Pholeomyia as monophyletic in her cladistic analysis of the family, obtaining as synapomorphies the presence of more than one postprotonal setae, the presence of three fronto-orbital setae, and the presence of three or four strong anepisternal setae. Brake (2000) did not include Pseudomilichia species as terminal taxa, but synonymized Pseudomilichia with Pholeomyia. She justified that the three synapomorphies defining Pholeomyia sensu stricto would also apply to all Pseudomilichia species, and that the emarginate eye of Pseudomilichia would be an insufficient character to define the genus.

Pseudomilichia was a small genus with only two described species (Pseudomilichia implicata Becker, 1907 and Pseudomilichia schnusei Becker, 1907), defined mainly by the combination of the presence of an emarginate eye and the presence of three or four strong anepisternal setae. The genus had already been synonymized with Pholeomyia by Hendel (1932), but his nomenclatural change was ignored by further authors-e.g., Hennig (1939). Instead, Hennig (1939) synonymized Macromilichia Hendel with Pseudomilichia. He also suggested that Macromilichia nigricosta Hendel, 1932 might be synonymous with Pseudomilichia schnusei, a pair of species that Brake (2000) accepted as valid. In the same study, Hennig synonymized Rhynchomilichia Hendel with Pholeomyia. After the synonymy proposed by Brake (2000), all Macromilichia, Rhynchomilichia and Pseudomilichia species have been included in Pholeomyia. It seems well established that Macromilichia and 
Rhynchomilichia would be synonymous of Pholeomyia, but questions about Pseudomilichia still remain.

Swann (2010) disagreed from Brake's (2000) synonymy and suggested that her synapomorphies for Pholeomyia would be homoplastic features evolving inside and outside Milichiinae. He mentioned, for example, that the presence of three or four strong anepisternal setae is also known to occur in some Eusiphona species. Following Swann (2000) and Sabrosky (1955), the presence of anepisternal setae may indicate a close relationship between Eusiphona and Pholeomyia, and even unite Eusiphona, Pholeomyia, and Pseudomilichia. Swann (2010) also points out that the presence of three frontal setae, considered by Brake (2000) as a synapomorphy of the genus, actually corresponds to a range of three to six frontal setae in Pholeomyia sensu stricto. Although it is not a unique condition within the subfamily, Swann (2010) considered Pseudomilichia a valid genus and the emarginated eye would be one of its defining features.

Brake's $(2000,2009)$ studies were a major step forward towards resolving the phylogenetic relationships within Milichiinae. Brake (2000) recovered Pholeomyia as sister of one of the branches of a paraphyletic Milichia. In Brake's (2009) taxonomic review and cladistics analysis of Milichiella, the Pholeomyia species included was recovered as sister group of Milichiella. As both analyses had limited number of species of Pholeomyia, a new cladistic reanalysis of the group with a wider taxonomic sampling may bring some shift to the conclusions on the monophyly of the genus and to its position in the system of the Milichiinae.

To properly address Brake's (2000) inferences for Pholeomyia, hence, it is necessary to broaden the sampling of species of the genus and properly sampling other Milichiinae genera to root the analysis and test the monophyly of Pholeomyia. Also, a detailed study of the male terminalia sclerites would highlight several unsolved questions in the evolution of the terminalia in milichiids. Finally, advances in the understanding of the phylogenetic relationships of the jackal flies shall provide an important background to future studies of evolutionary biology investigating the fascinating life histories of the family. 


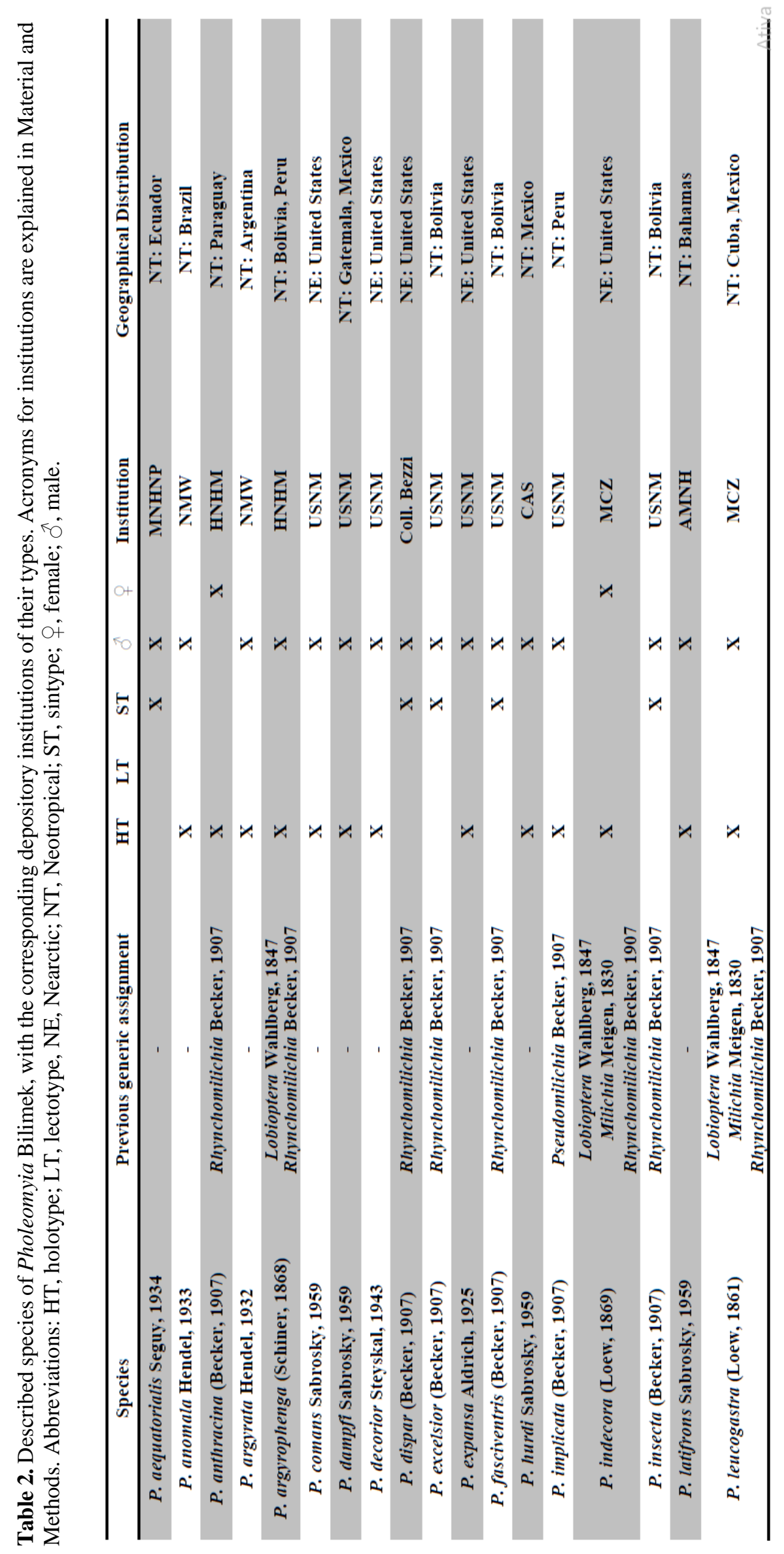




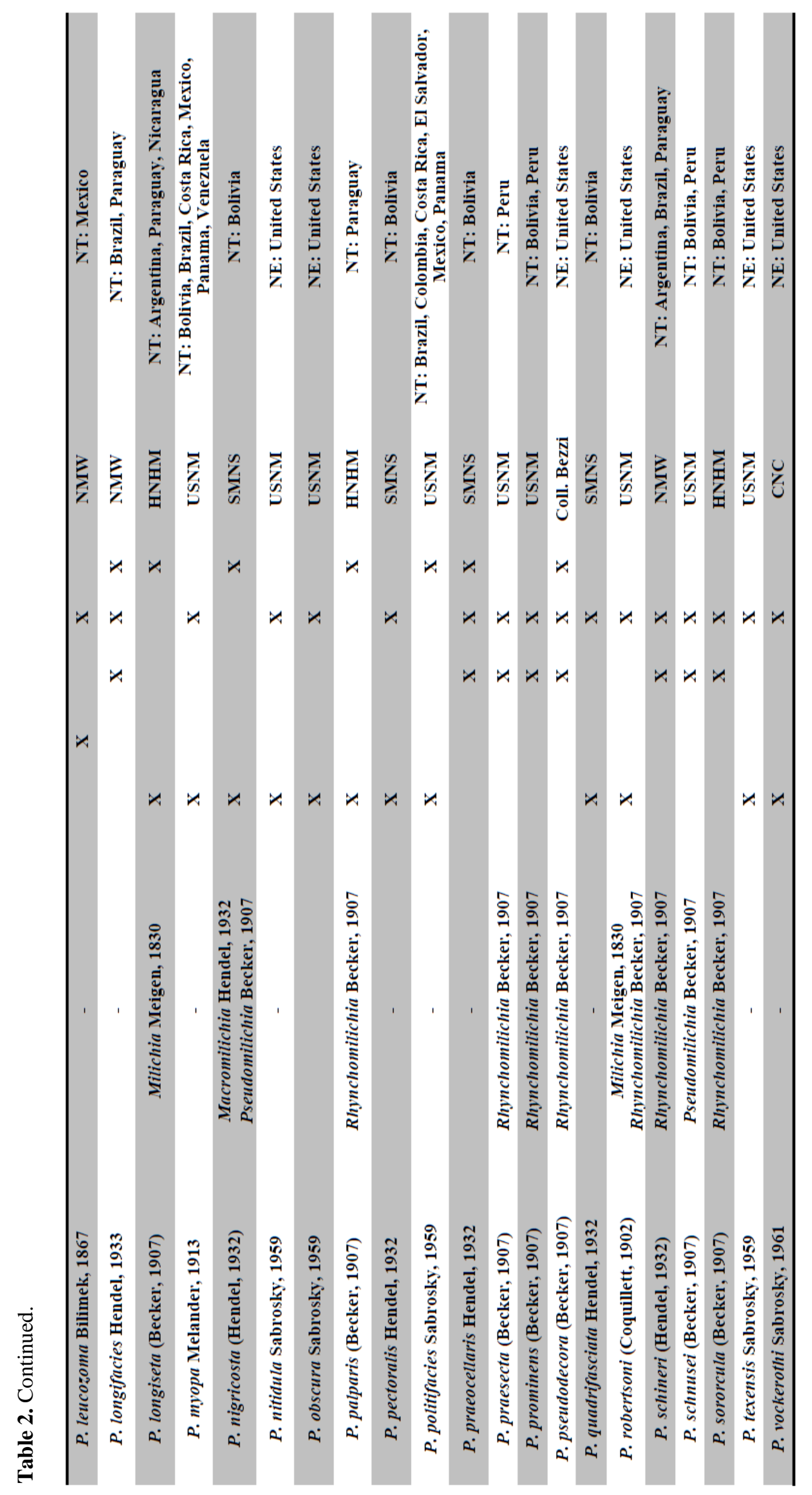




\section{CONCLUSIONS}

This study adressed the systematics of Pholeomyia, one of the most distinctive jackal fly genera, with a phylogenetic hypothesis for the genus. The taxonomic sampling of analysis was considerably extensive, allowing to further discuss the monophyly of Pholeomyia, the relationships within the genus, and the relationships between milichiine species.

Our results corroborate the hypothesis of a monophyletic Pholeomyia including the species assigned to Pseudomilichia. The sampling of the genus Milichia also reinforces the idea that this genus is paraphyletic in relation to Milichiella and to Pholeomyia. Our analysis increased the resolution of the relationships within Milichiinae. This study also highlights the gap in the knowledge of Pholeomyia diversity, with up to 30 potentially undescribed species that would add to the 28 described Neotropical species. The phylogeny obtained with 57 species of the genus show four main clades, which position and species composition may find some level of adjustment with the addition of male abdomen information in the data matrix for 12 of the species included as terminals in the analysis. 


\section{REFERENCES}

Becker, T. 1907. Die Dipteren-Gruppe Milichiinae. Annales Musei Nationalis Hungarici 5: 507-550.

Brake, I. 2000. Phylogenetic systematics of the Milichiidae (Diptera, Schizophora). Entomologica scandinavica Supplement 57: 1-120.

Brake, I. 2006. Diverse Milichiella Giglio-Tos (Diptera: Milichiidae) in Miocene Dominican amber. Insect Systematics \& Evolution 37: 371-394.

Brantjes, N.B.M. 1980. Flower morphology of Aristolochia species and the consequences for pollination. Acta Botanica Neerlandica, 29, 212-213.

Cumming, J.W. \& Wood, D.M. 2017. Adult morphology and Terminology [Chapter 3], In: Kirk-Spriggs, A.H. \& Sinclair, B.J. (Eds). Manual of Afrotropical Diptera. Volume 1. Introductory chapters and key to Diptera families. Suricata 4. South African Nacional Biodiversity Institute, Pretoria, pp. 89-133.

Donisthorpe, H. S. K. 1927. The guests of British ants: their habitats and life-histories. Routledge, London. xiii +244 pp.

Eisner, T., Eisner, M. \& Deyrup, M. 1991. Coattraction of kleptoparasitic flies to heteropteran insects caught by orbweaving spiders. Proceedings National Academy of Sciences, $88,8194-8197$.

Ferrar, P. 1987. A Guide to the Breeding Habits and Immature Stages of Diptera Cyclorrhapha, Volume 8 (2 parts). E. J. Brill, Leiden. pp. 256-258 (Part 1), 741-742 (Part 2).

Forey, P.L. \& Kitching, I. J. 2000. Experiments in coding multistate characters. In: Scotland R.W. Pennington R.T. (eds.). Homology and systematics: coding characters for phylogenetic analysis. London: Taylor and Francis, p. 54-80.

Goloboff, P.A., 1993. Estimating character weights during tree search. Cladistics 9: 8391.

Goloboff, P.A.; Farris, J.S. \& Nixon, K.C. 2008. TNT. A free program for phylogenetic analysis. Cladistics, 15: 415-428.

Hendel, F. 1932. Die Ausbeute del' deutschen Chaco-Expedition. 1925/26. Diptera XXXXXXVI. - Konowia 11 :98-110; 115-145, 15 figs.

Hennig, W. 1939. Beiträge zur Kenntnis des Kopulationsapparates und der Systematik der Acalyptraten. II. Tethinidae, Milichiidae, Anthomyzidae und Opomyzidae (Diptera). Arbeiten über morphologische und taxonomische Entomologie 6: 81-94. 
Monteith, G.B. 1982. Dry season aggregations of insects in Australian monsoon forests. Memoirs of the Queensland Museum 20: 533-543.

Nixon, K.C. 2002. WinClada ver. 1.00.08. Ithaca, NY. Publicado pelo autor, disponível em http://taxonomy.zoology.gla.ac.uk/rod.

Papp, L. \& T.A. Wheeler. 1998. 3.28. Family Milichiidae, pp. 315-324. In: Papp, L. \& Darvas , B. (Eds.). Contributions to a Manual of Palaearctic Diptera. Volume 3, Higher Brachycera. Science Herald Publishers, Budapest, 880 pp.

Robinson, M.H. \& Robinson, B. 1977. Associations between flies and spiders: bibiocommensalism and dipsoparasitism? Psyche, 84, 150-157.

Sabrosky, C. W. 1955. A third species of Eusiphona, with remarks on the systematic position of the genus (Diptera, Milichiidae). Ent. News 66:169-173.

Sabrosky, C.W. 1959. A revision of the genus Pholeomyia in North America (Diptera, Milichiidae). Annals of the Entomological Society of America 52: 316-331.

Sabrosky, C.W. 1973. 75. Family Milichiidae. In Papavero, N. (editor). A catalogue of the Diptera of the Americas south of the United States. Departamento de Zoologia, Secretaria da Agricultura, São Paulo, 12 pp.

Sabrosky, C.W. 1977. Family Milichiidae, pp. 270-274. In: Delfinado, M.D. \& Hardy, D.E. (Eds.). A catalog of the Diptera of the Oriental Region, Volume III. University Press of Hawaii, Honolulu, $\mathrm{x}+854$ pp.

Sivinski, J. \& Stowe, M. 1980. A kleptoparasitic cecidomyiid and other flies associated with spiders. Psyche, 87, 337-348.

Sivinski, J., Marshall, S. \& Petersson, E. 1999. Kleptoparasitism and phoresy in the diptera. Florida Entomologist, 82, 179-197.

Swann, J. E. 2010. Milichiidae. In: Brown, B.V., Borkent, A., Cumming, J.M., Wood, D.M., Woodley, N.E. \& Zumbado, M.A. (Eds.), Manual of Central American Diptera. Vol. 2. NRC Research Press, Ottawa, Ontario, Canadá, pp. 1125-113.

Swann, J. 2016. FAMILY MILICHIIDAE. Zootaxa, 4122 (1), 708-715.

Wild, A. \& Brake, I. 2009. Field Observations on Milichia patrizii Ant-Mugging Flies (Diptera: Milichiidae: Milichiinae) in KwaZulu-Natal, South Africa. African Invertebrates, 50(1), 205-212.

Wolda, H. \& C.W. Sabrosky. 1986. Insect visitors to two forms of Aristolochia pilosa in Las Cumbres, Panama. Biotropica, 18, 295-299. 
Young, A.D. \& Gillung J.P. 2020. Phylogenomics — principles, opportunities and pitfalls of big-data phylogenetics. Systematic Entomology, 45, 225-247. 